\title{
ЗАХОДИ ПРОФІЛАКТИКИ ІНФЕКЦІЙНИХ ЗАХВОРЮВАНЬ І ПІДВИЩЕННЯ ПРОДУКТИВНОСТІ У ПТАХІВНИЦТВІ
}

\author{
Чечет О. М., кандидат ветеринарних наук \\ Державний науково-дослідний інститут з лабораторної діагностики \\ та ветеринарно-санітарної експертизи, м. Київ, Україна \\ ORCID ID 0000-0001-5099-5577 \\ Kovalenkodoktor@gmail.com
}

Птахівнича галузь в Україні динамічно розвивається за рахунок економічної привабливості і досить швидкого повернення інвестицій, що стимулює інтенсифікацію вирощування птиці. Через це переущільнюється поголів'я, скорочуються санітарні розриви, що призводить до накопичення патогенної вірусної та бактеріальної мікрофрлори у навколишньому середовищі. Порушення ветеринарно-санітарних правил, низька якість кормів, збої у технології вирощування, стреси різного походження створюють умови для зниження резистентності організму птиці, послаблюють імунну систему і, як наслідок, стають причиною виникнення інфекційних хвороб різної етіології. Перебіз асоційованих інфекцій у латентній формі відбувається у більш тяжкій фрормі та більш тривалий час зі значною варіабельністю клінічних ознак і різними ускладненнями, що обтяжує проведення діагностичних і профрілактичних заходів. Окрім того, тісні зв'язки між вітчизняними та зарубіжними сільськогосподарськими товаровиробниками є основною причиною занесення на територію України збудників інфрекційних хвороб. Наявна загроза епізоотії та, відповідно, збитків для птахівництва вимагає застосування повного комплексу прогресивних програм імунної корекції і профрілактики захворювань, ефективних заходів біологічного захисту, що оптимізують метаболічні процеси в організмі птиці, підвищуючи природну резистентність. Мета роботи - вивчення, моніторине, аналіз, узагальнення та оцінка ринку імунобіологічних препаратів, біоцидів і кормових добавок для птахівничої галузі на сучасному етапі розвитку вітчизняного аграрного сектору. Аналіз запропонованих та офріційно зареєстрованих в Україні імуномодулюючих препаратів, антибіотиків, біоцидів, нутріцевтиків і кормових добавок для птахівниитва свідчить, що більшість із них (65,8\%) - це засоби, представлені зарубіжними виробниками, однак асортимент вітчизняної фрармакологічної індустрії (34,2\%) свідчить про високий потенціал українських виробників ветеринарних препаратів і кормових добавок для птахівничої галузі. Задля ефективної і пролонгованої дії цих заходів потрібно здійснювати систематичну ротацію біоцидів із метою запобігання виникненню стійкості збудників захворювань заразної етіології серед поголів'я птахів. Комплекс лікувально-профілактичних заходів має обов'язково враховувати локальну епізоотичну ситуацію, стійкість бактерій і вірусів до дії фрізико-хімічних фракторів і дезінфектантів, прогресивні та універсальні методи імунної модуляції організму птиці.

Для технологічної системи вирощування птахів нами запропоновано нові біоцидні препарати «Біолайд» $i$ «Діолайд». Комплексне використання препаратів на основі цих діючих речовин не потребує ротації дезінфрікуючих засобів і пролонгованої дії на патогенні мікроорганізми. Нами запропоновано також нові пробіотичні препарати «Біозапін» $i$ «Біомагн». Комплекс запропонованих препаратів покращить профрілактику інфрекційних хвороб і підвищить продуктивність у птахівництві.

Key words: заходи профрілактики, вакцини, антибіотики, біоциди, пробіотики, пребіотики, кормові добавки, птахівництво.

\section{DOI https://doi.org/10.32845/bsnau.vet.2021.3.9}

Вступ. Епізоотична ситуація, що склалась останніми десятиліттями в Україні, дає чітке розуміння, що єдиним ефективним заходом профілактики у птахівництві $€$ вакцинація. Значних економічних збитків птахівничим господарствам завдають інвазійні та вірусні інфекційні хвороби, рівень яких перевищує $60 \%$. Наявна загроза епізоотії і збитків для птахівництва змушує реагувати на випередження і проводити відповідні діагностичні дослідження, що дозволяє прогнозувати розвиток епізоотичного процесу, оцінювати можливі економічні втрати, своєчасно і правильно розробляти план лікувально-профілактичних заходів та ротаційні схеми дезінфекції (Bashchenko et al., 2017; Fisinin et al., 2018; Nechiporenko et al., 2021; Paliy et al., 2020).

Загальні принципи складання програм вакцинації дають змогу ефективніше підходити до вирішення проблем у випадках широко розповсюджених і важко викоренених інфекційних захворювань у птахівництві. Додаткові вакцинації слід узгоджувати і залучати до схем відповідно до локальної епізоотичної ситуації (Avdosieva et al., 2020; Bushuyeva et al., 2014).

Важливим аспектом імунізації птиці $€$ врахування різноманіття штамів застосовуваних вакцин у птахівничих господарствах. Нині у сучасному світі дослідники для вдосконалення та підвищення ефективності вакцинопрофрілактики використовують штами різного походження, водночас надаючи перевагу місцевим штамам.

Опціональні програми вакцинації передбачають складання найоптимальніших схем та індивідуальний підхід і враховують контроль ефективності попередніх програм (вакцин, біоцидів), обґрунтування доцільності використання препаратів, локальну епізоотичну ситуацію у кожному конкретному випадку, сучасні схеми дезінфекції. Ефективні інновації у заходах вакцинопрофілактики дають змогу аналізувати, оцінювати ризики, прогнозувати розвиток тих чи інших захворювань (Muzyka et al., 2013; Fisinin 2018; Nechiporenko et al., 2021). 
Збитки, спричинені захворюваннями, виражаються у зниженні і втраті продуктивності, зменшенні яйценосності, зниженні приросту ваги тіла птиці, у прямій смертності та прояві вторинних інфекцій унаслідок ураження імунної системи, у додаткових фрінансових витратах для проведення лікувальних і профілактичних заходів, погіршенні показників безпечності та якості продукції птахівництва (Breslavets et al., 2017; Rodionova, 2018).

Негативні наслідки таких захворювань можна успішно контролювати за допомогою вакцинації і впровадження надійних заходів біологічного захисту.

Мета роботи - вивчення, моніторинг, аналіз, узагальнення та оцінка ринку імунобіологічних препаратів, біоцидів і кормових добавок для птахівничої галузі на сучасному етапі розвитку вітчизняного аграрного сектору. Завдання роботи - підібрати діючі речовини і розробити профілактичні препарати для покращення системи технології вирощування птахів.

Матеріали та методи дослідження. Моніторинг, аналіз, узагальнення, оцінку ринку імунобіологічних препаратів і кормових добавок, офіційно зареєстрованих в Україні, ми проводили із застосуванням науково-теоретичних і практичних підходів до збору інформації у наукових джерелах і статистичних методів аналізу даних. Об'єктом досліджень були показники офіційного реєстру «Перелік кормових добавок, преміксів, готових кормів та ветеринарних препаратів», розміщеного на сайті Держпродспоживслужби http://consumer.gov.ua/ ContentPages/Reestri/38/, і Державного реєстру ветеринарних препаратів, кормових добавок, готових кормів і преміксів, розміщеного на сайті Державного науково-дослідного контрольного інституту ветеринарних препаратів та кормових добавок http://www.scivp.lviv. ua/uk/farmkomisija/rejestracija-veterynarnyh-preparativkormovyh-dobavok.html.

Результати досліджень. Станом на 2021 рік на ринку України зареєстровано 234 одиниці вакцин вітчизняного та іноземного виробництва, серед яких основну кількість становлять живі (148 одиниць), атенуйовані вакцини та інактивовані (69 одиниць), імунокомплексні (21 одиниця) та векторні. Застосування живих вакцин більш поширене (64\%) порівняно з інактивованими (32\%) та асоційованими (4\%) (рис.1). Частка клітинно-векторних вакцин на ринку України становить лише 0,1\%; такі препарати характеризуються меншим поширенням через високотехнологічні та досить вартісні методи їх синтезу.

Інактивовані вакцини містять інактивований вірус; вони виготовлені у формі емульсії із мінеральним маслом, яке виконує роль ад'юванта. У більшості випадків емульсії належать до типу «вода у маслі». Цей тип вакцин використовують для імунізації батьківських стад.

Живі вакцини виготовлені на основі класичних і варіантних штамів вірусу у формі ліофілізату. Залежно від рівня атенуації штаму і здатності долати материнські антитіла живі вакцини поділяють на м'які, проміжні, проміжні плюс, гарячі.

Імунокомплексні вакцини - це поєднання суспензії живого атенуйованого вірусу (штам проміжний плюс) у чітко визначених пропорціях 3 антитілами. Таким чином, вакцинний вірус укритий специфічними імуноглобулінами, які захищають його та не дозволяють розпізнаватись імунною системою птахів. Композиція імунокомплексних вакцин дозволяє атенуйованому вакцинному вірусу не зазнавати втручання материнських антитіл, отже, доставка вакцини безпечна незалежно від рівня материнських антитіл.

Векторні вакцини створені на основі генно-інженерного вірусу (вектора), геном якого містить ген від конкретного IBVD (донора), що кодує білок капсиду VP2. Незважаючи на те, що ці вакцини забезпечують належний захист, існує ризик ураження польовим вірусом.

Аналіз зареєстрованих в Україні вакцин для птахівничої галузі ми здійснювали з використанням інформації офріційного реєстру «Перелік ветеринарних імунобіологічних в Україні засобів кормових добавок, преміксів, готових кормів та ветеринарних препаратів», розміщеному на сайті Держпродспоживслужби.

Із загальної кількості офріційно зареєстрованих ветеринарних імунобіологічних засобів в Україні препаратів вітчизняного виробництва нараховується 36 одиниць, що становить 15,4\%, а закордонного походження - 198 одиниць, або 84,6\%. Щодо захворювань птиці, то найбільшою $€$ кількість зареєстрованих препаратів проти Ньюкаслівської хвороби (24\%), бурсальної хвороби птиці (хвороба Гамборо) (14,9\%), інфекційного бронхіту $(14,5 \%)$, синдрому зниження несучості курей $(9,1 \%)$, віспи птиці $(5,1 \%)$ та ринотрахеїту орнітобактеріального (5\%) (табл. 1).

Найактивнішими імпортерами ветеринарних імунобіологічних препаратів $€$ Нідерланди (16\%), Франція (13\%), США (10,6\%), Німеччина $(9,4 \%)$, Італія $(7,2 \%)$, Ізраїль (6,8\%), Великобританія (6,4\%), Іспанія (5,9\%), що графічно зображено на рис. 1. Водночас частка продукції українського виробництва на ринку становить 15\% і забезпечує його вакцинами проти всіх вищезазначених захворювань, що свідчить про досить потужний стан фармакологічної та науково-технічної галузей в Україні.

Проте вакцинація не завжди усуває проблеми, що виникають унаслідок упровадження інтенсивних технологій вирощування із високою концентрацією птиці на обмеженій площі. Це зумовлює виникнення і поширення інфекційних та інвазійних захворювань, що призводить до постійної потреби у застосуванні значної кількості ветеринарних препаратів із широким антимікробним спектром дії, зокрема антибіотиків. Попри законодавчу заборону використання антибіотиків із просрілактичною метою та як стимуляторів росту, дослідники фіксують їхнє широке використання (Abdel-Mohsein Hosnia Swafy et al., 2015; Fisinin, 2018; Kotsyumbas, 2016; Stoyanovsky, 2013).

В Україні для використання у птахівництві зареєстровано близько 244 видів антибактеріальних препаратів вітчизняного та імпортного виробництва, зокрема 34 комбінованих антибактеріальних препаратів, які дозволяється застосовувати для підтримання стабільної епізоотичної ситуації у птахівничих господарствах України. За діючою речовиною їх поділяють на 9 груп: $\beta$-лактами, фрторхінолони, тетрацикліни, поліміксини, макроліти, похідні тіамфеніколу, макроліди, аміноглікозиди, 
Перелік ветеринарних імунологічних препаратів для птиці, зареєстрованих на території України

\begin{tabular}{|c|c|c|c|}
\hline Назва захворювання & Форма препарату & Кількість, шт. & Країна-виробник \\
\hline Еймеріоз курей & Жива & 1 & Болгарія \\
\hline Кокцидіоз курей & Жива, жива атенуйована & 10 & $\begin{array}{l}\text { Болгарія, Великобританія, Канада, Чеська } \\
\text { республіка, США, Іспанія, Нідерланди }\end{array}$ \\
\hline Ньюкаслівська хвороба & $\begin{array}{l}\text { Жива, інактивована, } \\
\text { векторна клітинно- } \\
\text { асоційована }\end{array}$ & 58 & $\begin{array}{l}\text { Чеська республіка, Україна, Ізраїль, Україна, } \\
\text { Франція, Нідерланди, Республіка Хорватія, Іспанія, } \\
\text { США, Великобританія, Німеччина, Італія, Угорщина }\end{array}$ \\
\hline Інфекційний бронхіт & $\begin{array}{l}\text { Жива, інактивована, } \\
\text { асоційована інактивована }\end{array}$ & 34 & Україна, Ізраїль, Франція, Італія \\
\hline $\begin{array}{l}\text { Синдром зниженої } \\
\text { несучості }\end{array}$ & $\begin{array}{l}\text { Інактивована, інактивована } \\
\text { асоційована }\end{array}$ & 22 & $\begin{array}{l}\text { Україна, Нідерланди, Франція, Італія, Німеччина, } \\
\text { США, Ізраїль }\end{array}$ \\
\hline Сальмонельоз & Інактивована & 8 & $\begin{array}{l}\text { Україна, Нідерланди, Іспанія, Німеччина, США, } \\
\text { Ізраїль, Великобританія }\end{array}$ \\
\hline $\begin{array}{l}\text { Ринотрахеїт } \\
\text { орнітобактеріальний }\end{array}$ & Жива, інактивована & 12 & Україна, Нідерланди, Іспанія, Німеччина, Ізраїль \\
\hline Реовірусна інфекція курей & Інактивована & 7 & Нідерланди, Німеччина, США, Ізраїль \\
\hline Гемофільоз курей & Інактивована & 4 & Нідерланди, Німеччина, США, Ізраїль \\
\hline $\begin{array}{l}\text { Метапневмовірусна } \\
\text { інфекція птахів }\end{array}$ & Жива, інактивована & 7 & Нідерланди, Іспанія, Німеччина, Італія, Франція \\
\hline $\begin{array}{l}\text { Пневмовірусний } \\
\text { ринотрахеїт }\end{array}$ & Жива, інактивована & 10 & $\begin{array}{l}\text { Україна, Нідерланди, Іспанія, Франція, } \\
\text { Німеччина, Ізраїль }\end{array}$ \\
\hline $\begin{array}{l}\text { Синдром опухлої голови } \\
\text { курей }\end{array}$ & Жива & 1 & Іспанія \\
\hline $\begin{array}{l}\text { Бурсальна хвороба птиці } \\
\text { (хвороба Гамборо) }\end{array}$ & $\begin{array}{l}\text { Векторна клітинно- } \\
\text { асоційована, жива, } \\
\text { інактивована }\end{array}$ & 35 & $\begin{array}{l}\text { Україна, Ізраїль, Нідерланди, Франція, США, } \\
\text { Великобританія, Німеччина, Іспанія }\end{array}$ \\
\hline Віспа птиці & Жива, векторна & 14 & $\begin{array}{l}\text { Україна, Ізраїль, Нідерланди, Франція, США, } \\
\text { Великобританія, Німеччина, Іспанія }\end{array}$ \\
\hline Вірусний теносиновіт & Жива, інактивована & 5 & Україна, Італія, Нідерланди \\
\hline $\begin{array}{l}\text { Теносиновіт } \\
\text { (інфекційний артрит) }\end{array}$ & Жива, інактивована & 6 & Україна, Нідерланди, Франція, Німеччина, Італія \\
\hline
\end{tabular}

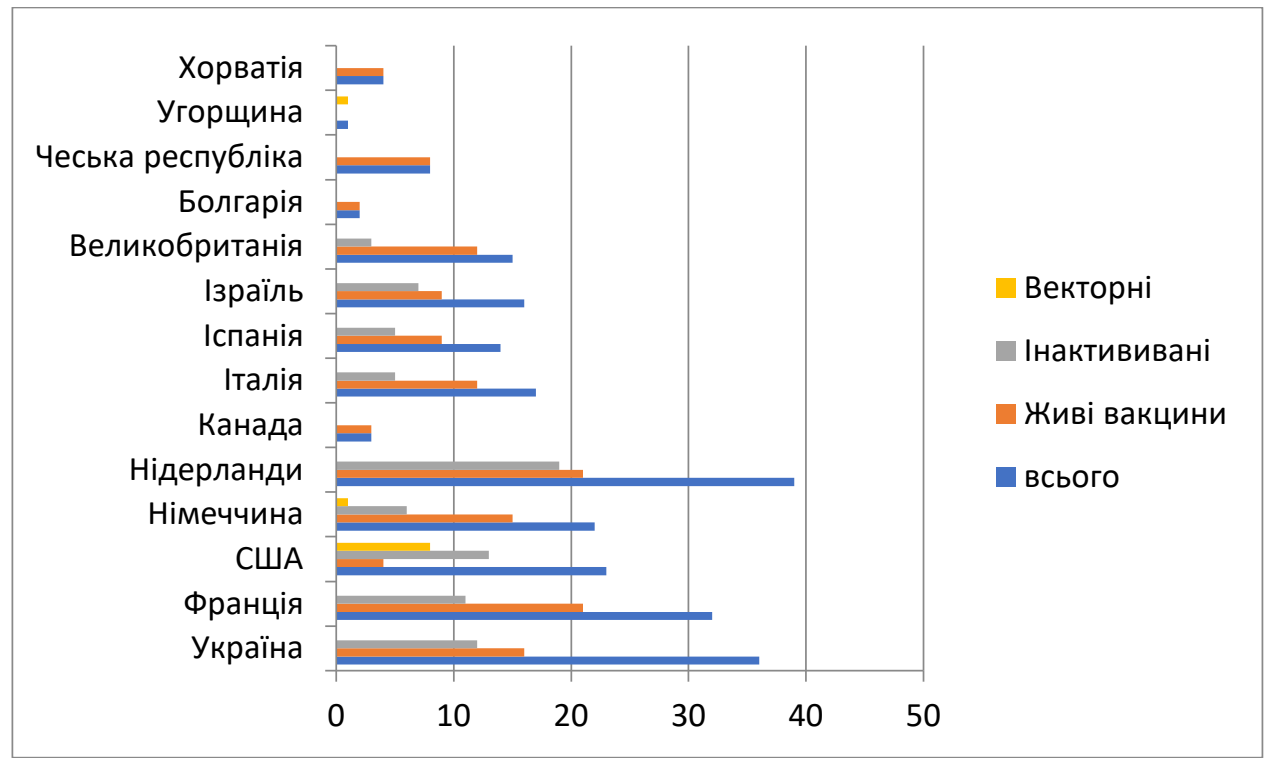

Рис. 1. Країни-імпортери ветеринарних імунобіологічних препаратів в Україні

плевромутиліни (Abdel-Mohsein Hosnia Swafy, 2015; Stoyanovsky, 2013; Stoyanovsky et al., 2012; Voronetskaya et al., 2016, c. 46,47). Унаслідок проведеного аналізу ми визначили пріоритетні та найпоширеніші антибактеріальні препарати для застосування у птахівничій галузі України. Встановлено, що найбільша частка зареєстрованих антибіотиків (від 22,0 до 18,0\%) припадає на групи фрторхінолонів, макролідів, тетрациклінів та $\beta$-лактамів. Антибіотики груп аміноглікозидів, полімексинів, похідних тіамфеніколу, плевромутилінів також входять до переліку зареєстрованих і дозволених для використання у птахівничій галузі, проте їхня частка становить від 7,0 до 15,0\%. Менше реєструють антибіотики групи лінкозамідів і сульфамідні препарати (рис. 2). 


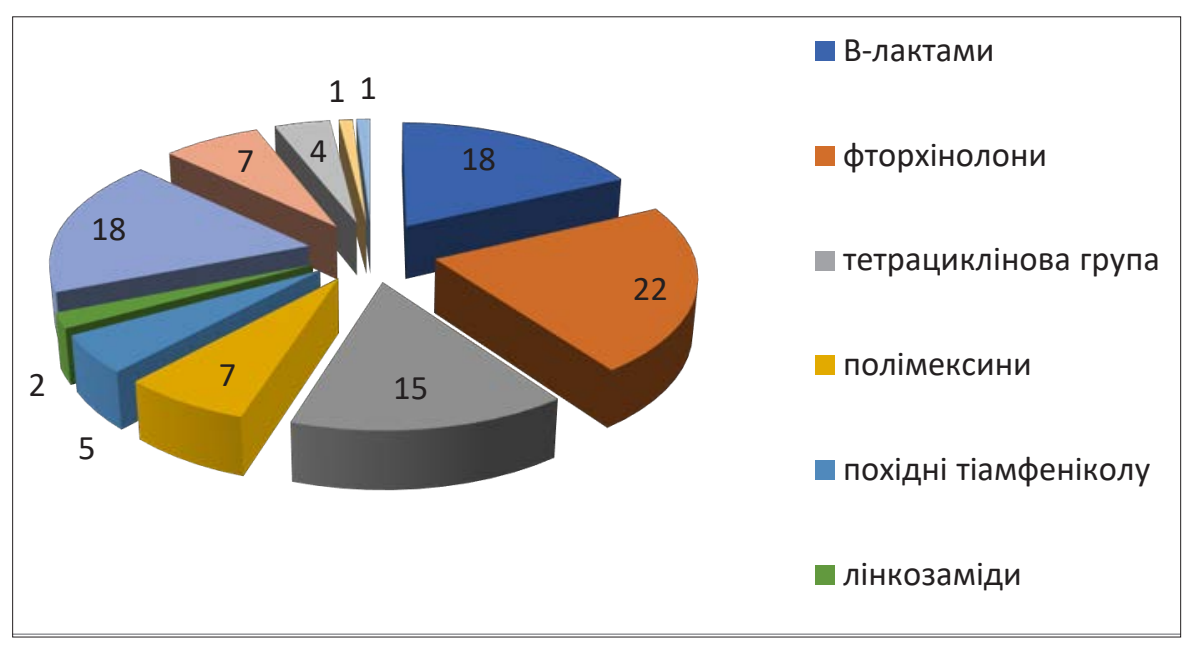

Рис. 2. Спектр антимікробних препаратів, дозволених для використання у птахівничій галузі України (станом на 01.01.2021р.)

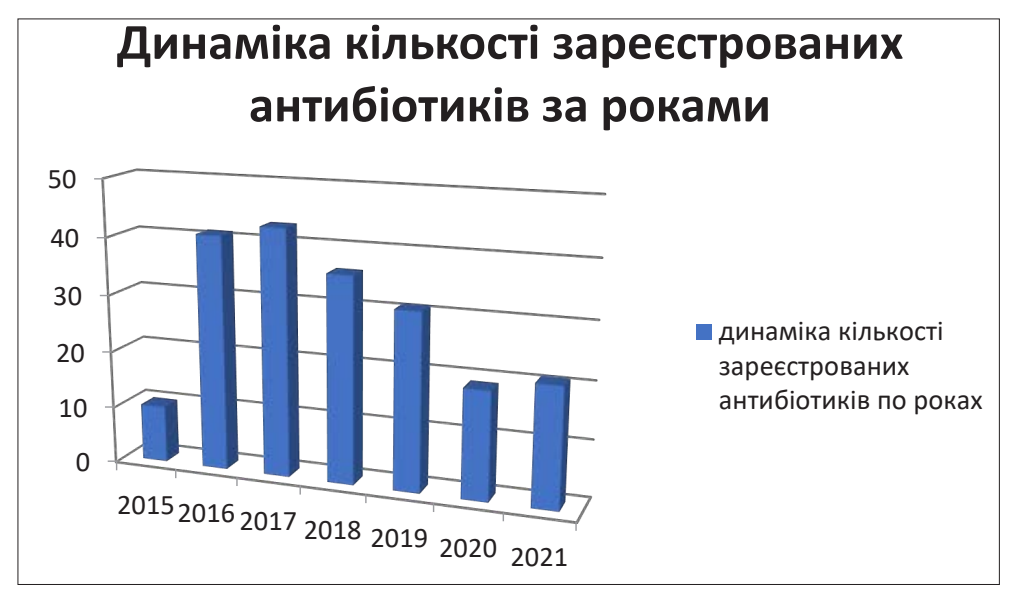

Рис. 3. Кількість антибіотиків, зареєстрованих в Україні та дозволених для використання у птахівництві впродовж 2015-2021 рр.

Проте найбільшу кількість антибіотиків, що входять до реєстру, віднесено до комбінованих. Їхня частка становить 20,5\% від усіх зареєстрованих антибактеріальних препаратів. Діючі речовини, що входять до складу комбінованих препаратів, належать до груп тетрациклінів, макролідів та $\beta$-лактамів, аміноглікозидів, хінолонів (Abdel-Mohsein Hosnia Swafy et al., 2015; Stoyanovsky, 2013). Треба відмітити, що щорічно ринок антибактеріальних препаратів України поповнюється новими засобами. Про це свідчить той факт, що із 2015 по 2021 рік зареєстровано 164 різновидів антибіотиків, а у 2017 році - найбільшу їх кількість (43 препарати) (Abdel-Mohsein Hosnia Swafy et al., 2015; Fisinin, 2018; Garkavenko, 2017) (рис. 3).

Водночас результативність проведення будь-яких лікувально-профрілактичних заходів залежить від комплексного застосування засобів дезінфекції для створення розриву епізоотичного ланцюга. Для вирішення цієї проблеми використовують біоцидні продукти, призначені для руйнування, знешкодження або пригнічення бактерій, вірусів і грибків хімічним або біологічним шля- хом. Основними факторами, що впливають на дієвість таких засобів, $є$ спектр антимікробної дії (ефективність проти вірусів, бактерій, спор за різних температур середовища і зміни $\mathrm{pH}$, відсутність мутагенного ефекту на мікроорганізми), безпечність дезінфіктанту (відсутність ембріотоксичних, тератогенних, канцерогенних, алергенних та кумулятивних властивостей), корозійна активність, висока проникна здатність, екологічна безпечність. Дослідниками встановлено, що річна потреба біоцидів для галузі вітчизняного виробництва перевищує 3 тисячі тонн (Mund et al., 2017). Аналіз офіційного ринку ветеринарних дезінфікуючих засобів ми проводили за матеріалами реєстрації препаратів для ветеринарної медицини. В Україні для галузі птахівництва пропонується 161 дезінфектант (94\% від кількості зареєстрованих). Серед них $58,1 \%$ - це засоби, представлені закордонними виробниками, однак досить широкий спектр продуктів вітчизняної фармакологічної індустрії свідчить про високий потенціал українських виробників засобів захисту тварин. Із них найбільший відсоток становить група із лужних засобів $(67,9 \%)$, біоцидів на основі альдегідів 
(переважно глютаровий альдегід). Другу за величиною групу (12,4\%) формують дезінфікуючі засоби на основі четвертинних амонієвих сполук (ЧАС). Третю групу $(11,1$ \%) утворюють кислотовмісні дезінфікуючі засоби. Решту $(8,6 \%)$ становлять біоциди на основі хлору та засоби на основі тільки ЧАС без альдегідів, а також кисень-, хлор -, йод - і срібловмісні сполуки. Водночас через наростаюче впровадження у практику дезінфікуючих засобів виникає проблема можливого формування стійкості до них бактерій. Відомо, що в основі резистентності мікроорганізмів до дезінфікуючих засобів лежить генотипний механізм, ще не досить вивчений. Установлено, що характер формування стійкості мікроорганізмів до біоцидних засобів та антибіотиків є різним: у першому випадку - хромосомний, у другому - плазмідний, що загалом ускладнює підбір дезінфікуючих препаратів. Ураховуючи те, що зростання резистентності до деяких груп дезінфікуючих засобів може набувати латентний характер, періодично слід проводити ротацію дезінфектантів (Albero et al., 2018; Bashchenko et al., 2017; Bordunova, 2013; Breslavets, 2017; Berezovsky, 2018; Bushuyeva, 2014; Fotina, 2015; Kirillov, 2018; Kovalenko, 2012; Kovalenko, et al., 2020; Muzyka, 2013; Nechiporenko, 2021; Nechiporenko, et al., 2018; Rodionova, 2018; Zavgorodny, 2013). Стратегія профілактики інфекцій у промисловому птахівництві базується на комплексі заходів, спрямованих на ефективне знешкодження збудників захворювань на будь-якому етапі їх розвитку.

Аналізуючи табл. 2, ми спостерігаємо, що кількість кислотовмісних та активних щодо кисню препаратів майже вдвічі більше, ніж вітчизняних препаратів. За результатами наших досліджень, найоптимальнішими діючими речовинами за ефективністю, ціною і можливістю застосовувати у присутності тварин $є$ перекис водню, надмолочна кислота, молочна кислота (препарат «Біолайд») і діоксид хлору (препарат «Діолайд»). Комплексне використання препаратів на основі цих діючих речовин не потребує ротації дезінфікуючих засобів та пролонговано впливає на патогенні мікроорганізми.

Нині вже накопичено значну базу експериментальної наукової інформації, що засвідчує невпинне збільшення кількості вірулентних варіантів мікроорганізмів, резистентних до антибіотиків і біоцидів різних видів. Ускладнення щодо цього чинить знижена імунна реактивність сприйнятливої птиці. Підвищенням дієвості імунобіологічних засобів може слугувати введення у схеми лікувально-профілактичних заходів різних препаративних форм супроводу, зокрема пребіотиків, пробіотиків, імуностимуляторів, вітамінів (Avdeeva et al., 2015; Garkavenko, 2017; Kirillov, Prudius, 2018; Kotsyumbas, 2016; Melnichenko, 2016; Palii, et al., 2020; Sentıes-Cue. et al., 2016).

Численними дослідженнями встановлено, що нутріцевтики делікатно налагоджують процеси травлення, збільшують засвоюваність кормів, поліпшують біохімічні показники крові та фрізіологічний стан птиці, стимулюють асиміляційні процеси та метаболічні реакції в організмі птиці, що призводить до підвищення опірності та неспецифічної резистентності, збільшення приросту маси, підвищення продуктивності (Kirillov, Prudius, 2018; Kotsyumbas, 2016; Melnichenko, 2016; Palii, et al., 2020).

Універсальним рішенням у птахівництві є пробіотики, що мінімізують застосування антибіотиків. Новітні пробіотики (моноштамові та поліштамові) містять представників нормальної коменсальної мікрофлори - лакто- та біфідобактерії - із антибактеріальними та імуномодулюючими властивостями (Garkavenko, 2017; Kotsyumbas, 2016). Існують 2 форми пробіотиків: висушені та рідкі препарати. Ліофілізовані форми пробіотиків мають низку недоліків, зокрема характеризуються тривалим виходом мікробних клітин зі стану анабіозу (8-10 годин) в оптимальних умовах культивування, які можна забезпечити лише у лабораторіях. В умовах шлунково-кишкового тракту (ШКТ) за цей проміжок часу більша частина пробіотичних клітин може елімінуватися. В організмі хазяїна значна частина ліофілізованої мікрофрлори гине ще до реактивації в агресивних умовах ШКТ. Значно ефективнішими є «живі» пробіотики у вигляді рідкої суспензії у спеціальному захисному середовищі. У таких препаратах бактерії перебувають у фізіологічно активній формі та можуть діяти відразу після прийому препарату. Пробіотичні мікроорганізми у вигляді рідкої форми $є$ активнішими та життєздатнішими в агресивних умовах ШКТ, не потребують тривалої реактивації, проявляють свою дію одразу після введення в організм (Garkavenko, 2017, c. 13; Palii, et al., 2020). У сукупній дії такі препарати чинять дезінтоксикаційну та імуномодуляційну дію; підвищують рівень бактерицидної активності сироватки крові; збереженість і приріст живої маси молодняка; компенсують дефіцит біологічно активних речовин в організмі птиці, що виникає внаслідок хвороби і проведення профрілактичних щеплень та дегельмінтизацій; забезпе-

Таблиця 2

Характеристика дезінфектантів для птахівництва, зареєстрованих в Україні за складом діючої речовини (станом на 2021 рік)

\begin{tabular}{|c|c|c|c|c|c|c|c|c|c|c|}
\hline \multirow[b]{2}{*}{ Виробники } & \multirow[b]{2}{*}{$\begin{array}{c}\text { Кількість, } \\
\text { од. }\end{array}$} & \multirow[b]{2}{*}{ Альдегіди } & \multicolumn{8}{|c|}{ Групи діючих речовин } \\
\hline & & & $\begin{array}{c}\text { ЧАС + } \\
\text { альдегіди }\end{array}$ & Кислотовмісні & ЧAC & $\begin{array}{l}\text { Кисень } \\
\text { активні }\end{array}$ & $\begin{array}{c}\text { Хлор } \\
\text { активні }\end{array}$ & $\begin{array}{c}\text { Йод } \\
\text { активні }\end{array}$ & $\begin{array}{l}\text { Срібло } \\
\text { активні }\end{array}$ & Інші \\
\hline Вітчизняні & 68 & 28 & 14 & 7 & 5 & 4 & 4 & 2 & 2 & 2 \\
\hline Зарубіжні & 93 & 32 & 15 & 14 & 11 & 9 & 4 & 4 & 2 & 2 \\
\hline Всього & 161 & 60 & 29 & 21 & 16 & 13 & 8 & 6 & 4 & 4 \\
\hline
\end{tabular}


чують стійкість організму до надмірного навантаження під час транспортування, вакцинації, зміни раціону. У комплексі вакцинопрофрілактики ремонтного молодняка яйценосних курей такі препарати забезпечують зростання середніх титрів антитіл та посилюють імунну відповідь на вакцину, забезпечуючи збільшення відсотку поголів'я носіїв антитіл.

На вітчизняному ринку ветеринарних препаратів (за фрармакотерапевтичними групами) біопрепарати разом із пробіотиками становлять 29,6\% від загальної кількості препаратів, які застосовуються для тварин і птиці всіх видів. Причиною дисбалансу у потребі та використанні пробіотичних препаратів саме у птахівництві $€$ недостатня кількість високоефективних і недорогих пробіотичних препаратів (Avdeeva et al., 2015; Fisinin, 2018; Garkavenko, 2017).

Нині в Україні офріційно зареєстровано 14 препаратів, які характеризують як біологічні імуностимулюючі та пробіотичні засоби, із них 11 препаратів (78,6\%) вітчизняного та 3 - імпортного виробництва (14,2\% поставляє Німеччина, 7,1\% - Великобританія) (табл. 3).

Під час проведення аналізу вітчизняних і зарубіжних діючих речовин пробіотичних препаратів нами підібрано і розроблено нові пробіотичні препарати: «Біозапін» (на основі суміші пробіотичних бактерій Bacillus sybtilis, Bacillus amyloliquefaciens та алюмосилікату) та «Біомагн» (на основі магнію хлориду, хітозану, суміші пробіотичних бакерій Bacillus subtilis, Bacillus licheniformis, Enterococcus faecium та висушених продуктів фрерментації мікроорганізмів Lactococcus Lactis, Bacillus subtilis, Bacillus licheniformis).
Препарат «Біозапін» призначений для оброблення поверхонь, знищення запаху у місцях утримання тварин, додавання у підстилку, де утримуються тварини. Він застосовується для знищення запаху аміаку, сечовини. Специфічні властивості компонентів зумовлюють пролонговану дію засобу.

Пробіотичний препарат «Біомагн» застосовується для додавання у раціони із високим умістом клітковини, кукурудзи, сої. Переважно призначається для розщеплення непоживних некрохмалистих полісахаридів, крохмалю. Застосовується для відновлення мікрофлори кишечника, а також як детоксикант. Уводиться у комбікорми, білково-вітамінні добавки, білково-мінеральні вітамінні добавки для поліпшення продуктивності тварин, підвищення продуктивності бройлерів, збільшення несучості у курей-несучок. За рахунок додаткового звільнення поживних речовин можна досягти поліпшення конверсії корму.

Ефективність використання вищезазначених засобів може значно зростати у разі комплексного застосування їх із якісними кормовими та мінеральними добавками. У сучасному кормовому виробництві України наявний досить великий вибір кормових добавок і препаратів, які використовують для стимулювання збільшення приростів маси $(46,3 \%)$ у межах стратегії заміни кормових антибіотиків (38,9\%), для їхніх протизапальних ефектів $(38,9 \%)$ і для поліпшення коефіцієнта конверсії корму $(30,2 \%)$ (Avdeeva et al., 2015; Bushuyeva et al., 2014). До їхнього складу входять макро- і мікроелементи, вітаміни, екзогенні ензими, пробіотики, пребіотики, бактеріофаги, які літично діють на збудників, не проявляючи водночас

Перелік імуностимулюючих пребіотичних препаратів для птиці, зареєстрованих на території України

\begin{tabular}{|c|c|c|}
\hline Назва препарату & Виробник препарату & Країна-виробник \\
\hline АМІКСИН & ТДВ "ІНТЕРХІМ" & Україна \\
\hline Ентеронормін & ТОВ «СГП МБС» & Україна \\
\hline Ентеронормін Детокс & ТОВ «СГП МБС» & Україна \\
\hline $\begin{array}{c}\text { Альбікан }{ }^{\circledR} \text {, Albican }{ }^{\circledR} \text { - препарат біологічний } \\
\text { імуномодулючий для лікування і профрілактики } \\
\text { алергічних хвороб шкіри та дихальних шляхів у тварин }\end{array}$ & $\begin{array}{l}\text { БІНОМЕД ГмбХ; ПУП «Гомельський завод } \\
\text { ветеринарних препаратів» }\end{array}$ & $\begin{array}{l}\text { Німеччина/ } \\
\text { Білорусь }\end{array}$ \\
\hline $\begin{array}{c}\text { Бінольбін }{ }^{\circledast}, \text { Binolbin }{ }^{\circledast}-\text { препарат біологічний } \\
\text { імуномоделюючий для лікування і профілактики } \\
\text { алергічних та вірусних кон'юнктивітів у тварин }\end{array}$ & $\begin{array}{l}\text { БІНОМЕД ГмбХ; ПУП «Гомельський завод } \\
\text { ветеринарних препаратів» }\end{array}$ & $\begin{array}{l}\text { Німеччина, } \\
\text { Білорусь }\end{array}$ \\
\hline Біспорин & $\begin{array}{c}\text { Державне підприємство «Сумська біологічна } \\
\text { фрабрика» }\end{array}$ & Україна \\
\hline Авігард ${ }^{\circledR}$, Aviguard $^{\circledR}$ & Лаллеманд Енімал Нутрішн ЮК, ЛТД & Велика Британія \\
\hline Плацевіт & $\begin{array}{c}\text { ТОВ "СмартБіоЛаб"; ТОВ "НДП Ветеринарні } \\
\text { біотехнології" }\end{array}$ & Україна \\
\hline "IMУСТАРТ+" & $\begin{array}{c}\text { ТОВ "СмартБіоЛаб"; ТОВ "НДП Ветеринарні } \\
\text { біотехнології" }\end{array}$ & Україна \\
\hline Пробіотик «ТIMM-C» & $\begin{array}{c}\text { Державне дослідне підприємство Інституту } \\
\text { продовольчих ресурсів Національної академії } \\
\text { аграрних наук України }\end{array}$ & Україна \\
\hline $\begin{array}{l}\text { ПРОБІОТИК "LactoPharm LP12" } \\
\text { (Лактофрарм LP 12)" }\end{array}$ & $\begin{array}{c}\text { Херсонське державне підприємство - } \\
\text { біологічна фабрика }\end{array}$ & Україна \\
\hline Пробіотик «Споро-лекс» & ТОВ УКРБІОТЕХ & Україна \\
\hline $\begin{array}{l}\text { "СОРБФЛОР", "SORBFLOR" } \\
\text { - пробіотичний засіб із } \\
\text { підкислювачем та сорбентом }\end{array}$ & $\begin{array}{c}\text { Херсонське державне підприємство - } \\
\text { біологічна фабрика }\end{array}$ & Україна \\
\hline $\begin{array}{c}\text { "ВІTАФЛОР", "VITAFLOR" - пробіотичний засіб із } \\
\text { адаптогеном і підкислювачем }\end{array}$ & $\begin{array}{c}\text { Херсонське державне підприємство - } \\
\text { біологічна фабрика }\end{array}$ & Україна \\
\hline
\end{tabular}


токсичної дії на макроорганізм (Bushuyeva et al., 2014; Kalinichenko, 2016; Kirillov, 2019; Kirillov, 2017; Kyryliv, Prudius, 2018; Kirillov, 2018; Kovalenko, 2012; Khizhnyak, 2012; Melnichenko, 2016; Paliy, Stegniy, 2018; Polishchuk, Bulavkina, 2010; Starovoitova, Karpov, 2015). Ці речовини мають різну біологічну природу і первинні механізми дії, водночас вони балансують стан нормофрлори кишечнику та активізують продуктивність птиці. Станом на 2021 рік в Україні для потреб птахівничої галузі зареєстровано 249 кормових добавки (13,6\% вітчизняного та 86,3 імпортного виробництва), 49 преміксів для птиці та свійських видів тварин (28,6\% вітчизняного та $71,4 \%$ імпортного виробництва); мінеральні, вітамінно-мінеральні і технологічні добавки (6 одиниць зарубіжного походження) (табл. 4). Серед регіонів світу основний обсяг пропозиції кормової продукції зосереджено в Азії та в Європі, а найбільшим споживачем кормів $є$ країни Європи (близько 60\% загального обсягу кормів) (рис. 4). Найпотужнішими країнами-виробниками кормів є Китай, США і Бразилія (Bordunova, 2013; Nechiporenko, at al., 2020; Paliy, at al., 2020). Серед країн Євросоюзу лідируючі позиції у виробництві кормових ресурсів для галузі птахівництва посідає Франція.

Таблиця 4

Перелік зареєстрованих кормових добавок і преміксів для птиці в Україні

\begin{tabular}{|c|c|c|}
\hline Назва & Кількість & Країна виробництва \\
\hline Кормові добавки & 249 & $\begin{array}{c}\text { Україна - 34, зарубіжного } \\
\text { виробництва - 215 }\end{array}$ \\
\hline Премікси & 49 & $\begin{array}{c}\text { Україна - 14, зарубіжного } \\
\text { виробництва - 35 }\end{array}$ \\
\hline $\begin{array}{c}\text { Мінерально-вітамінні } \\
\text { добавки }\end{array}$ & 2 & США, Польща \\
\hline Мінеральні добавки & 3 & Чехія, Польща \\
\hline Технологічні добавки & 1 & Німеччина \\
\hline
\end{tabular}

Перелік кормових добавок нараховує значну кількість кормових засобів, які за призначенням поділяються на протеїнові, енергетичні, мінеральні, вітамінні добавки; антибіотики, ферментні препарати; пробіотики, пребіотики; підкислювачі; інгібітори плісняви; адсорбенти токсинів; комбіновані добавки. Протеїнові добавки сприяють підвищенню показників росту птиці, відповідно, і продуктивності. До енергетичних добавок відносять пропіленгліколь; сухі форми жирів для тварин, що складаються із жирних кислот, пальмового масла та кон'югованих лінолевих кислот. Мінеральні добавки - це органічні та неорганічні солі металів і природні джерела: алюмосилікати (цеоліти, сапоніти та інші), сапропель. Кормові ферменти не впливають прямо на мікрофлору кишечника, але вони позитивно діють на корми. Ензимні композиції руйнують некрохмальні полісахариди клітинних оболонок, роблячи крохмаль і білок зерна більш доступним для травної системи тварин і птиці. Ферменти - природні каталітичні речовини, які впливають на головні обмінні процеси в організмі. Їхнє застосування сприяє ефективній підготовці та засвоєнню кормів в організмі тварин та їх здешевленню (до 10\%). Проте найпоширенішими $€$ комбіновані кормові добавки, до складу яких входить декілька біологічно активних речовин; це найбільша група добавок нового покоління. Вони мають стабілізуючі та імуностимулюючі властивості; підвищують середньодобові прирости живої маси відгодівельного молодняка на 7,3-9,4\%, дорослої птиці - до 12\%; покращують обмін кальцію, фосфору, заліза, міді, цинку, магнію, кобальту, йоду (Bushuyeva et al., 2014; Kalinichenko, 2016; Kirillov, 2019; Kirillov, 2017; Kyryliv, Prudius, 2018; Kirillov, 2018; Kovalenko, 2012; Khizhnyak, 2012).

Висновки. На тлі глобалізації сучасного світу і збільшення обсягів міжнародних торгівельних операцій із перевезень тварин, птиці, сільськогосподарської продукції значно загострюються ризики щодо транскордонного занесення і швидкого поширення інфекційних захворювань, а також розповсюдження патогенів, які їх зумовлюють, як в окремих регіонах, так і на території держави.

Під час моніторингу ринку імуномодулюючих препаратів, антибіотиків, біоцидів, нутріцевтиків і кормових добавок, зареєстрованих в Україні, встановлено, що незначна більшість із них $(65,8 \%)$ - це засоби, запропоновані зарубіжними виробниками, однак асортимент вітчизняної фармакологічної індустрії $(34,2 \%)$ свідчить про високий потенціал українських виробників ветеринарних препаратів і кормових добавок для птахівничої галузі.

Промислове птахівництво в Україні в умовах глобальної епізоотичної ситуації та можливого виникнення емерджентних інфекційних хвороб потребує застосування повного комплексу прогресивних програм імунокорекції і профілактики захворювань, ефективних заходів біологічного захисту, що оптимізують метаболічні процеси в організмі птиці та підвищують природну резистентність.

Для ефективної та пролонгованої дії цих заходів потрібно здійснювати систематичну ротацію біоцидів, препаратів для імунізації птиці із метою запобігання виникненню стійкості збудників захворювань заразної етіології серед поголів'я птахів. Комплекс лікувально-профілактичних заходів має обов'язково враховувати локальну епізоотичну ситуацію, стійкість бактерій і вірусів до дії фрізико-хімічних фракторів дезінфектантів, прогресивні та універсальні методи імуномодуляції організму птиці.

До технологічної системи вирощування птахів ми запропонували внести такі нові біоцидні препарати: «Біолайд» (на основі перекису водню, надмолочної кислоти, молочної кислоти) та «Діолайд» (на основі діоксиду хлору). Комплексне використання препаратів на основі цих діючих речовин не потребує ротації дезінфікуючих засобів та пролонгованої дії на патогенні мікроорганізми.

Ми запропонували також нові пробіотичні препарати: «Біозапін» (на основі суміші пробіотичних бактерій Bacillus sybtilis, Bacillus amyloliquefaciens та алюмосилікату) і «Біомагн» (на основі магнію хлориду, хітозану, суміші пробіотичних бакерій Bacillus subtilis, Bacillus licheniformis, Enterococcus faecium та висушених продуктів ферментації мікроорганізмів Lactococcus Lactis, Bacillus subtilis, Bacillus licheniformis).

Комплекс запропонованих препаратів покращить профрілактику інфекційних хвороб та підвищить продуктивність у птахівництві. 


\section{Бібліографічні посилання:}

1. Avdeeva, L.V., Lazarenko, L.M., Melnichenko, Y.O. (2015). Immunomodulatory properties of synbiotic compositions of probiotic strains of Bacillus subtilis, lactite or lactulose [ Imunomoduliuvalni vlastyvosti synbiotychnykh kompozytsii probiotychnykh shtamiv Bacillus subtilis, laktytu abo laktulozy ]. Microbiological Journal, 77(1), $20-25$ (in Ukrainian).

2. Avdosieva, I.K., Tchaikovsky, O.I., Basarab, O.B., Regenchuk, V.V. (2020). Prevention of infectious encephalomyelitis of birds [Profilaktyka infektsiinoho entsefalomiielitu ptytsi]. Lviv, 1(1),18-22. doi: 10.36359/scivp.2020-21-2.02 (in Ukrainian).

3. Abdel-Mohsein, Hosnia Swafy, Manal, Abdalla Mohamed Mahmoud, AwadAbdel-Hafez, Ibrahim. Tetracycline Residues in Intensive Broiler Farms in Upper Egypt: Hazards and Risks J. World'sPoult. Research Paper. September 25, 2015, 5(3), 48-58. [Electronic resource]. Access mode: http://jwpr.scienceline.com/attachments/article/33/J\%20World's\%20 Poult\%20Res\%205(3)\%2048- 58,\%202015.pdf

4. Azirkina, I.M. (2020). Scientific and practical substantiation of application of microbiological methods of determination of antibiotic residues in poultry products: dis.: 16.00.03[Scientific and practical substantiation of application of microbiological methods of determination of antibiotic residues in poultry products]. Kyiv, 186 (in Ukrainian).

5. Albero, B., Tadeo, J.L., Escario, M., Miguel, E., Pérez, R.A. Persistence and availability of veterinary antibiotics in soil and soil-manure systems. Sci. Total Environ, 2018, 643. P.1562-1570. DOI: 10.1016/j.scitotenv.2018.06.314

6. Bashchenko, M.I., Stegniy, B.T., Gerilovich, A.P. (2017). Problems and prospects of development of standards of biological safety and biological protection in veterinary medicine and biotechnology. Problemy i perspektyvy rozvytku standartiv biolohichnoi bezpeky ta biolohichnoho zakhystu u veterynarnii medytsyni ta biotekhnolohii. Veterinary medicine, 103, 8-13 (in Ukrainian).

7. Bordunova, O.G. (2013). The use of disinfectants in industrial poultry: scientific practice. rekom. [Vykorystannia dezinfikuiuchykh preparativ u promyslovomu ptakhivnytstvi : nauk.-prakt. rekom]. Sumy, 39, 31 (in Ukrainian).

8. Breslavets, V.O., Glebova, K.V., Yaroshenko, M.O., Pavlichenko, O.V., Stegniy, O.O. (2017). Use of biocidal products for disinfection of hatching eggs of. chickens. [Vykorystannia biotsydnykh preparativ dlia dezinfektsii inkubatsiinykh yaiets kurei]. Modern. poultry breeding, 3(4), 20-24 (in Ukrainian).

9. Berezovsky, A.V., Nechiporenko, O.L., Fotina, G.A., Petrov, R.V. (2018). Study of properties and application of experimental biocide for treatment of poultry premises. [Vyvchennia vlastyvostei ta zastosuvannia eksperymentalnoho biotsydu dlia obrobky ptakhivnychykh prymishchen]. Veterinary medicine, 104, 218-223 (in Ukrainian).

10. Bushuyeva, I.V., Berezovsky, A.V., Knysh, E.G., Panasenko, O.I. (2014). The use of the drug "avesstim" to increase the effectiveness of vaccine prophylaxis and the effect of the drug on the resistance of chickens [Zastosuvannia preparatu «avesstym» dlia pidvyshchennia efektyvnosti vaktsynoprofilaktyky ta vplyv preparatu na rezystentnist kurchat]. Scientific Journal «ScienceRise», 4/1(4), 94-98. DOI: 10.15587/2313-8416.2014.29279

11. Fisinin, V.I. (2018). Strategic trends in world and domestic poultry: the state, challenges, prospects. World and Russian trends in poultry development: realities and challenges of the future [Strategicheskiye trendy razvitiya mirovogo $\mathrm{i}$ otechestvennogo ptitsevodstva: sostoyaniye, vyzovy, perspektivy. Mirovyye i rossiyskiye trendy razvitiya ptitsevodstva: realii i vyzovy budushchego]: materials of the XIX International. conf. Sergiev Posad: FNC "VNITIP" RAS, 46-48 (in Russian).

12. Fotina, G.A. (2015). Pharmaco-toxicological and clinical assessment of chemotherapeutic tools for rotation schemes in ptakhivnistvi [Farmako-toksykolohichna ta klinichna otsinka khimioterapevtychnykh zasobiv dlia skhem rotatsii v ptakhivnytstvi]: author. dis. ... Dr. vet. Sciences: 16.00.04. Lviv. 41 p. (in Ukrainian).

13. Garkavenko, T.A. (2017). Antibiotic resistance of pathogens of bacterial infections of animals in Ukraine. Actual problems of intensive development of animal husbandry [Antybyotykorezystentnost vozbudytelei bakteryalnыkh ynfektsyi zhyvotnыkh v Ukrayne. Aktualnыe problemы yntensyvnoho razvytyia zhyvotnovodstva].Gorki, 20, $234-240$ (in Russian).

14. Kalinichenko, S.V. (2016). Modern directions of creation and improvement of probiotics [Suchasni napriamky stvorennia ta udoskonalennia probiotykiv]. Ukrainian Biopharmaceutical Journal, 1 (42), 4-9 (in Ukrainian).

15. Kirillov, B. Y. (2019). Species, ontogenetic and organo-tissue features of protein metabolism and activity of hydrolytic enzymes in poultry under the action of alimentary factors: dis. dock. of Agricultural Sciences [Vydovi, ontohenetychni ta orhano-tkanynni osoblyvosti proteinovoho obminu y aktyvnist hidrolitychnykh enzymiv u ptytsi za dii alimentarnykh chynnykiv: dys. dok. silskohospodarskykh nauk].03.00.04. Lviv, 353 (in Ukrainian).

16. Kirillov, B. Y. (2017). Influence of biologically active feed additives on the activity of digestive processes in the body of broiler ducks [Vplyv biolohichno aktyvnoi kormovoi dobavky na aktyvnist travnykh protsesiv $\mathrm{v}$ orhanizmi kacheniatbroileriv.]. Agricultural science and food technology, 3(97), 68-73 (in Ukrainian).

17. Kyryliv, B. Ya., Prudius, T. Ya. (2018). Influence of "Activio" and "BiloActiv" drugs on poultry productivity [Vplyv preparativ "Aktyvio" i "BiloAktiv" na produktyvnist ptytsi]. Modern poultry farming, 9(10), 6-11 (in Ukrainian).

18. Kirillov, B. Ya. (2018). The effectiveness of the use of biologically active feed additive "White-Acts" in the diets of quails [Efektyvnist vykorystannia biolohichno-aktyvnoi kormovoi dobavky «Bilo-Aktiv» v ratsionakh perepeliv]. Modern poultry farming, 3(4), 12-17 (in Ukrainian).

19. Kirillov, B. Ya., Prudius, T. Ya. (2018). Secondary plant compounds are a means of reducing the use of antibiotics and improving the efficiency of feeding [Vtorynni roslynni spoluky - zasib zmenshennia vykorystannia antybiotykiv ta pokrashchennia efektyvnosti hodivli]. Modern poultry farming, 7(8), 11-15 (in Ukrainian).

20. Kovalenko, V.L. (2012). Theoretical and experimental substantiation of development and use of complex disinfectants for veterinary medicine [Teoretychne i eksperymentalne obgruntuvannia rozrobky ta vykorystannia kompleksnykh dezinfektantiv dlia veterynarnoi medytsyny]: author's ref. dis. Dr. Vet. Science, Kiyv, 23 (in Ukrainian).

21. Kovalenko, V. L. et al. (2020). Evaluation of acute toxicity of the "Orgasept" disinfectant. Ukr. J. Ecol., 10 (4), 273-278. doi: 10.15421/2020_199

22. Kotsyumbas, G.I. (2016). Histological, histochemical characteristics and morphometric and microbiological parameters of the caecum of broiler chickens when feeding feed with different probiotic content [Histolohichna, histokhimichna 
kharakterystyka ta morfometrychni i mikrobiolohichni pokaznyky slipykh kyshok kurei-broileriv za zghodovuvannia kormiv z riznym vmistom probiotykiv]. Animal biology, 18(1), 52-60 (in Ukrainian).

23. Khizhnyak, O.S. (2012). Biotechnological aspects of drug development based on probiotics [Biotekhnolohichni aspekty stvorennia preparativ na osnovi probiotykiv]. Bulletin of NTU "KhPI", 44 (950), 72-78 (in Ukrainian).

24. Lisova, N.E., Zhila, M.I., Avdosieva, I.K. et al. (2015). Influence of polybionic feed mixture on the body of broiler chickens. Scientific and technical byul [Vplyv kormovoi sumishi polibionika na orhanizm kurchat-broileriv]. DNDKI veterinary drugs and feed additives. Institute of Animal Biology, 16(1), 147-151 (in Ukrainian).

25. Mandigra, Y.M. (2017). Sanitary assessment of the use of disinfectants based on polyhexamethylene guanidine in animal husbandry [Sanitarna otsinka zastosuvannia u tvarynnytstvi dezinfikuiuchykh zasobiv na osnovi poliheksametylenhuanidynu]: dis. Candidate of Agricultural Sciences: 16.00.06. Kharkiv, p. 147 (in Ukrainian).

26. Melnichenko, Yu. M. (2016). Biotechnology of probiotic supplement production and its use for growing broiler chickens [Biotekhnolohiia oderzhannia probiotychnoi dobavky ta yii vykorystannia za vyroshchuvannia kurchat-broileriv]: dis. Candidate of Agricultural Sciences, 03.00.20, Bila Tserkva, 142 (in Ukrainian).

27. Stoyanovsky, V. G., Kolomiets, I.A., Kolotnytsky, V.A., Kamratska, O.I. (2013). Microecological system of broiler intestines and methods of its bionormalization [Mikroekolohichna systema kyshechnyku broileriv ta sposoby yii bionormalizatsii]. Scientific Bulletin of LNUVMBT named after S.Z. Gzycki, 3(57), 319-322 (in Ukrainian).

28. Tarasenko, G.V., Garkavenko, S.S., Borshchevskaya, N.M., Nishchyshyn, M.M., Popova, M.E.(2019). Biocidal and deodorizing agent based on essential oil vegetable raw materials [Biotsydnyi ta dezodoruiuchyi zasib na osnovi efirooliinoi roslynnoi syrovyny]. Physical and organic chemistry, pharmacology and pharmaceutical technology of biologically active substances: a collection of scientific works, 2(2), 36-43 (in Ukrainian).

29. Mund, M. D., Khan, U. H., Tahir, U., Bahar-EMustafa, Fayyaz, A. (2017). Antimicrobial drug residues in poultry products and implications on public health: A review. International Journal of Food Properties, 20 (7), 1433-1446 (Electronic resource). Access mode: https://www.tandfonline. DOI: 10.1080/10942912.2016.1212874

30. Muzyka, D. V. (2013). Antigenic activity of experimental series of inactivated vaccine against highly pathogenic avian influenza with different levels of hemagglutinins [Antyhenna aktyvnist eksperymentalnykh serii inaktyvovanoi vaktsyny proty vysokopatohennoho hrypu ptytsi z riznym rivnem hemahliutyniniv] Scientific Bulletin of Veterinary Medicine, 11, 172-175. http://nbuv.gov.ua/UJRN/nvvm 2013 1148

31. Nechiporenko, O.L. (2021). Pharmaco-toxicological evaluation of new biocides for rational schemes of their rotation for the production of safe livestock products [Farmako-toksykolohichna otsinka novykh biotsydiv dlia ratsionalnykh skhem yikh rotatsii za vyrobnytstva bezpechnoi produktsii tvarynnytstva]: dis. Doctor of Veterinary Sciences: 16.00.04, 16.00.03. Sumy. 421 p. (in Ukrainian).

32. Nechiporenko, O.L., Berezovsky, A.V., Petrov, R.V., Fotin, A.I. (2018). Investigation of biocidal properties of the domestic drug "DezSan" [Doslidzhennia biotsydnykh vlastyvostei vitchyznianoho preparatu «DezSan»] Veterinary biotechnology, 32(1), 155-161 (in Ukrainian).

33. Nechiporenko, O.L., Shkromada, O.I., Shkvarkovskaya, V.N. (2018). Study of the disinfecting properties of the drug "ADG" for disinfection of veterinary laboratories on the market. Problems of zooengineering and veterinary medicine [Doslidzhennia dezinfikuiuchykh vlastyvostei preparatu «ADG» dlia dezinfektsii veterynarnykh laboratorii na rynku], 35(2), 107-110 (in Ukrainian).

34. Nechiporenko, O.L., Berezovsky,A.V., Fotina, T.I., Petrov, R.V.(2018). The effectiveness of comprehensive disinfection measures in poultry farming [Efektyvnist kompleksnykh dezinfikuiuchykh zakhodiv $\mathrm{v}$ umovakh ptakhohospodarstva]. Scientific Bulletin of LNUVMB named after SZ Gzhytsky, 20(92), 165-168 (in Ukrainian).

35. Paliy, A.P., Stegniy, B.T. (2018). Practical aspects of disinfection in the system of biosecurity and biosafety in veterinary medicine [Praktychni aspekty dezinfektsii $v$ systemi biozakhystu ta biobezpeky u veterynarnii medytsyni]. Vet. Medicine: interdepartmental. topic. Science, 104, 62-65 (in Ukrainian).

36. Paliy, A.P. et al. (2020). Scientific and methodical bases of control of development and application of means of disinfection [Naukovo-metodychni osnovy kontroliu rozrobky ta zastosuvannia zasobiv dezinfektsii]: monograph. Kharkiv: Miskdruk, 318 p. (in Ukrainian).

37. Palii A. P. et al. (2020). Effect on the bactericidal device for decontamination the air microorganisms in poultry house on the content of toxic gases. Ukr. J. Ecol., 10 (1), 24-29 (in Ukrainian).

38. Paliy, A. P. et al. (2018). Distribution of poultry ectoparasites in industrial farms, farms, and private plots with different rearing technologies. Biosyst. Divers, 26 (2), 153-159 (in Ukrainian).

39. Polishchuk, A.A., Bulavkina, T.P. (2010). Modern feed additives in animal and poultry feeding [Suchasni kormovi dobavky v hodivli tvaryn ta ptytsi] Bulletin of the Poltava State Agrarian Academy, 2, 63-66 (in Ukrainian).

40. Rodionova, K.O. (2018). Sanitary and hygienic assessment and disinfection of objects of veterinary supervision at meat processing enterprises [Sanitarno-hihiienichna otsinka ta dezinfektsiia ob'iektiv veterynarnoho nahliadu na m'iasopererobnykh pidpryiemstvakh]: author's ref. dis. ... Cand. vet. Science. Kharkiv. 21 p. (in Ukrainian).

41. Sentıes-Cue, C.G., Gallardo, R.A., Reimers, N., Bickford, A.A., Charlton, B.R., Shivaprasad, H.L. (2016). Avian encephalomyelitis in layer pullets associated with vaccination. Avian Dis. 60(2), 511-515.

42. Starovoitova, S.O., Karpov, O.V. (2015). Prospects for the use of probiotic microorganisms in functional foods and medicine [Perspektyvy vykorystannia probiotychnykh mikroorhanizmiv v funktsionalnykh produktakh kharchuvannia ta medytsyni]. Food Industry, 18, 76-80 (in Ukrainian).

43. Stoyanovsky, V.G., Kolomiets, I.A., Kamratskaya, O.I., Kolotnitsky, V.A. (2012). Physiological state of the body of broiler chickens in critical age periods with the use of immunocorrective drugs on the background of vaccination [Fiziolohichnyi stan orhanizmu kurchat-broileriv u krytychni vikovi periody pry zastosuvanni imunokoryhuiuchykh preparativ na tli vaktsynatsii] Scientific Bulletin of LNUVMBT named after S.Z. Gzycki, 14(3), 236-239 (in Ukrainian). 
44. Voronetskaya, S.I., Kravchuk, O.O., Korniychuk, G.V. (2016). Scientific and practical principles of the feed market [Naukovo-praktychni zasady funktsionuvannia rynku kormiv]. Agrosvit, 20, 3-10 (in Ukrainian). A. Zavgorodny, A.I. and others (2013). Scientific and practical aspects of disinfection in veterinary medicine [Naukovi ta praktychni aspekty dezinfektsii u veterynarnii medytsyni]. Kharkiv. p. 222 (in Ukrainian).

45. Official website of the State Service of Ukraine for food safety of food products and zhistu sposivachiv [Electronic resource]. Access mode: https://dpss.gov.ua/diyalnist/reyestrividkritidani

46. Official website of State Scientific and Preliminary Control Institute of Veterinary Drugs and Feed Additives veterinary drugs and feed additives [Electronic resource]. Access mode: http://www.scivp.lviv.ua/uk/farmkomisija/rejestracijaveterynarnyh-preparativ-kormovyh-dobavok.html

Chechet O. M., Candidate of Veterinary Sciences, State Scientific and Research Institute of Laboratory Diagnostics and Veterinary and Sanitary Expertise, Kyiv, Ukraine

Measures for prevention of infectious diseases and increasing productivity in poultry

The poultry industry in Ukraine is growing dynamically due to economic sustainability and relatively fast recovery of investments, which stimulates the intensification of poultry breeding. Violation of veterinary and sanitary rules, poor quality of forage, disruptions in breeding technology, stress different causes create conditions leading to a decrease in resistance of the bird's body, weaken the immune system and, as a result, lead to infectious diseases of different etiologies. The present danger of epizootic diseases and losses incurred to poultry requires the use of a full range of progressive programs of immune correction and prevention of disease, effective bio-protection measures, which optimize metabolic processes in the bird's body, increasing natural resistance. The purpose of the work was to study, monitor, analyze, summarize and evaluate the market of immunobiological drugs, biocides and feed additives for poultry industry at the current stage of development of the national agrarian sector. The analysis of requested and officially registered in Ukraine immunomodulatory drugs, antibiotics, biocides, nutraceuticals and feed additives for poultry breeding shows that a small majority of them (65.8\%) are foreign products, while the range of domestic pharmaceutical products (34.2\%) indicates a high potential of Ukrainian producers of veterinary drugs and feed additives for poultry industry. For efficient and prolonged action of these treatments a systematic rotation of biocides is necessary in order to prevent etiologic diseases of becoming more resilient. The complex of medical and preventive measures must necessarily take into account local epizootic situation, resistance of bacteria and viruses against physical and chemical factors of disinfectants, progressive and universal methods of immunomodulation of bird organism.

We proposed a new biocidal drugs "Biolide" and "Diolide" in the technological system of growing poultry. Complex use of preparations based on these active substances does not require rotation of disinfectants and prolonged action on pathogens. As well as new probiotic drugs Biosapin and Biomagnes. The complex of suggested preparations will increase the prevention of infectious diseases and improve the productivity of poultry breeding.

Key words: Preventive measures, vaccines, antibiotics, biocides, probiotics, prebiotics, feed additives, poultry keeping. 